\section{Economic Assessment of Biodiesel Production for Hungarian Farmers*}

\author{
Attila Bai \\ University of Debrecen, Centre of Agricultural Sciences, \\ Institute of Agricultural Economics and Rural Development, \\ Department of Farm Business Management, Debrecen
}

\section{SUMMARY}

Utilisation of oil of plant origin as a fuel is gaining acceptance in the European Union and elsewhere. Besides environmental protection, energy saving, and decreasing overproduction of food. Additionally, the subsidisation of farmers and the development of rural sub-regions also contribute to its spread. This study specifically focuses on the direct effects biodiesel's raw materials and final products are now having on farmers, while reviewing and quantifying these effects. I have purposely restricted my analysis to these two elements of the biodiesel chain.

The biodiesel chain seems to be a great method for improving the economic and social position of participant farmers in many ways. Presently, the profitability of raw materials' production looks to be the crucal point in the chain, and could be strengthened best with intensive, habitat-specific agrotechnic. It would only be possible to reach a favourable profit margin for farmers if yields reach unrealistic averages or if there is a significant hike of the 2000 producer's price in the oil plant branch.

The main attraction of sunflower- and oilseed rape production lies in the stabilization of market conditions, which is not only gong to appear in oil plant branch but - thanks to the reduction of outputs - also in the cereal branches. Better economic safety for farmers may play a role at least on the same level as in plant production, which involves more risks than profit maximalization.

The reduction of the prime cost of biodiesel could be possible through the direct combustion of the whole oilseed plant or its residues or electricity production using them. Whereas energy demand for biodiesel production is low (appr. 5\%) but it needs subsidization and the prices of natural gas and electrical energy presently look favourable in Hungary. Additionally harvesting and baling of the residues is technically problematic, which is why their use may seem to be reasonable just over the middle or long term. Another possible factor of cost reduction could be the centralization of some partial operations, which needs serious financial resources to reduce amortization cost per product, provided there be several biodiesel projects near each other during establishment. Creation and operation of a logistical system could also be a good method for improving the viability of the biodiesel chain, in order to optimize transport schedule and distances. However there are also some organizational difficulties in this case.

\section{GENERAL ECONOMIC ASPECTS}

For farmers, it is worth producing oil-plants if these plants are compatible with other plants, the interest rate of banks, the local rental fee of land, as well as cheaper fuel can be developed than gasoline, and if they provide proper perspectives even after joining the European Union with the available capital (money, machinery) and marketing facilities. On this basis I examine the situation of farmers using comparative analysis.
Rape and sunflower / other field plants / interest rate and rental fee of land

$>$ Biodiesel / utilisation of gasoline in agricultural production.

I intend to deal with the expected effects of joining the EU in another study. According to the above mentioned facts, it is clear that farmers' interests are diametrically opposed: on the one hand, they are interested in increasing the production price of oil plants (as well as the costs of raw materials of biodiesel), while on the other hand, they want to decrease the price of biodiesel they use themselves. This contraversion can only be solved by significant state subsidy or by marketing biodiesel, which may cause financial and controlling problems.

Due to the large investment need, the crucial point of biodiesel production - excluding financial aspects - is the full utilisation of capacity. In my opinion, regulations on founding biodiesel factories control this in a proper way. If convincing farmers to take in oil plants into crop rotation is not successful, there will be two negative effects for biodiesel factories:

Higher purchasing price will be induced by saler's market

$>$ Transaction costs relating to transportation will rise because of the distant or multi-sited purchasing.

These factors may increase the prime costs of biodiesel, which has to be financed by the state budget if it intends to maintain the compatible production price of biodiesel compared to preferential gasoline price as well as the operation of integrated production and the utilisation system of biodiesel.

\section{COMPARING THE OILSEED RAPE AND SUNFLOWER WITH OTHER CULTIVATED PLANTS}

One of the very favourable characteristics of these two plants is that they can be produced using wheat machinery (outfitted with a special adapter). As this machinery is outside the peak time, they can make better use of their own equipment, and decrease their possible production prices with only a minimum of extra investment. Thus, I am going to compare oilseed rape and sunflower production with those of winter wheat and corn (Table 1). 
Table 1: The most important economical facts relating to oil plants, winter wheat and corn

\begin{tabular}{|c|c|c|c|c|c|c|c|c|c|c|c|}
\hline \multirow{2}{*}{2000} & \multirow{2}{*}{ Unit } & \multicolumn{4}{|c|}{ Oilseed rape } & \multicolumn{4}{|c|}{ Sunflower } & \multirow{2}{*}{$\begin{array}{c}\text { Wheat } \\
(1) \\
\end{array}$} & \multirow{2}{*}{$\begin{array}{c}\text { Corn } \\
(1) \\
\end{array}$} \\
\hline & & $(1)$ & $(2)$ & (3) & (4) & $(1)$ & $(2)$ & (3) & (4) & & \\
\hline Revenues (5) & thHUF/ha & 65 & 103 & 103 & 84 & 77 & 116 & 116 & 94 & 123 & 157 \\
\hline Production costs & thHUF/ha & 86 & 124 & 138 & 119 & 96 & 135 & 150 & 131 & 117 & 143 \\
\hline Labor costs (6) & thHUF/ha & 5 & 6 & 5 & 5 & 5 & 6 & 5 & 5 & 6 & 7 \\
\hline Overhead costs & thHUF/ha & 5 & 8 & 8 & 7 & 6 & 9 & 9 & 8 & 9 & 12 \\
\hline Variable costs & thHUF/t & 19 & 19 & 20 & 20 & 18 & 18 & 19 & 19 & 10 & 13 \\
\hline Fixed costs (7) & thHUF/ha & 52 & 68 & 80 & 72 & 61 & 81 & 93 & 85 & 72 & 72 \\
\hline Average yield & $\mathrm{t} / \mathrm{ha}$ & 1,5 & 2,5 & 2,5 & 2 & 1,6 & 2,5 & 2,5 & 2 & 3,6 & 4,5 \\
\hline Market price (2000. October) & thHUF/t & 38 & 38 & 38 & 38 & 43 & 43 & 43 & 43 & 32 & 33 \\
\hline Prime costs & thHUF/t & 57 & 49 & 55 & 60 & 60 & 54 & 60 & 66 & 33 & 32 \\
\hline Net profit (8) & thHUF/ha & -21 & -21 & -35 & -35 & -19 & -20 & -34 & -37 & 6 & 14 \\
\hline Profit sharedby production costs & $\%$ & -24 & -17 & -25 & -29 & -20 & -14 & -23 & -28 & 5 & 10 \\
\hline Gross profit (9) & thHUF/ha & -16 & -15 & -30 & -30 & -14 & -14 & -29 & -32 & 12 & 21 \\
\hline Gross overhead margin (10) & thHUF/ha & -16 & -13 & -27 & -28 & -13 & -11 & -25 & -29 & 15 & 26 \\
\hline Remaining costs (11) & thHUF/ha & 2 & 2 & 0 & 0 & 2 & 2 & 0 & 0 & 0 & $2(4)$ \\
\hline Minimum efficient scale (12) & $\mathrm{t} / \mathrm{ha}$ & 2,32 & 3,16 & 4,00 & 3,56 & 2,12 & 2,92 & 3,54 & 3,21 & 2,91 & 3,20 \\
\hline
\end{tabular}

Sources: basic facts by KITE, IKR, expert opinion and own estimations

Legend: (1) estimated (expectable) national average with own machine stock, (2) KITE, IKR technologies (1996-1999) with own machines, (3) KITE, IKR technologies (1996-1999) with hired machines, (4) expectable average yield for farmers in the biodiesel chain with own tillage machines but with other hired machines, (5) (revenues x average yield) + state subsidy ( 8 thHUF/ha), (6) manualist, tractor-driver (when till the soil), overhead activity (excluding hired services), (7) including the amount which can be required from gasoline ( 8 thHUF/ha), (8) revenues - production costs, (9) net profit + labor costs, (10) net profit + overhead costs, (11) fixed costs of special unmovable assets, (12) including 8 thHUF/ha state subsidy

Production of oil plants in 2000 was profitable for only very few farmers due to the unfavourable weather, small parcels, negligence of the optimum in agronomy and production site and the low producer's price. Present prices do not stimulate even reasonable use of inputs: 18-20 thHUF variable cost is needed for 1 tonne of additional product in oil-plants. This is the reason why, in this year, pretty high yields, 2.3 $\mathrm{t} /$ ha oilseed rape and $2.1 \mathrm{t} /$ ha sunflower, might have been enough to reach zero economic result with own machinery under average production conditions. The smallest prime cost is expected at yields of 3 to 3.5 t/ha under optimum production conditions of both plants. Reaching this yield could make the highest profit for farmers, and produce the cheapest biodiesel. 41-46 thHUF/t production price in rape and 44-48 thHUF/t in sunflower would provide highest profit, over the interest bank rate and rental fee of land for producers farming intensively, depending on the rate of hired service without landbased subsidy, while presently it would have been more useful for them to rent their land and put their money used for movable assets into a bank.

Reaching a yield of $2 \mathrm{t} / \mathrm{ha}$ could mean a suitable result in both oil-plants in Hungary. Regardless of the land-based subsidy, zero profit could be reached under higher producer's prices, that is, 56 thHUF/t (oilseed rape) and 62 thHUF/t (sunflower), for those who intends to hire all necessary machines. Minimum prices of zero profit belonging to different yields are illustrated in Figure 1 and 2 (without landbased state subsidy).

Figure 1: Minimum producer's price for zero profit in the case of differential average yields

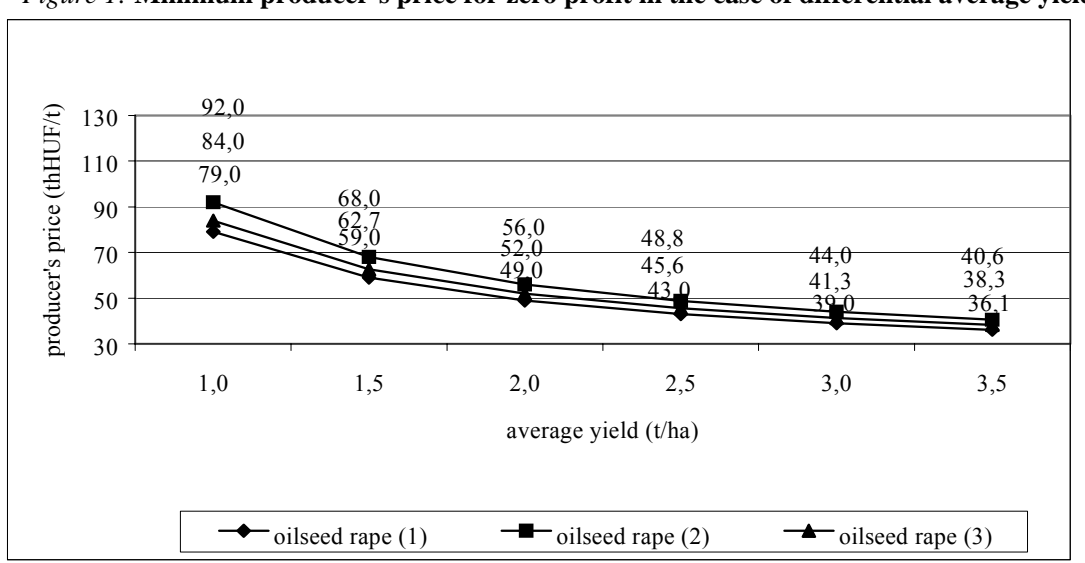

Source: own calculations

Legend: (1) use of KITE, IKR technologies (1996-1999) with own machines, (2) use of KITE, IKR technologies (1996-1999) with hired machines, (3) use of KITE, IKR technologies (1996-1999) with own tillage machines but with other hired machines 


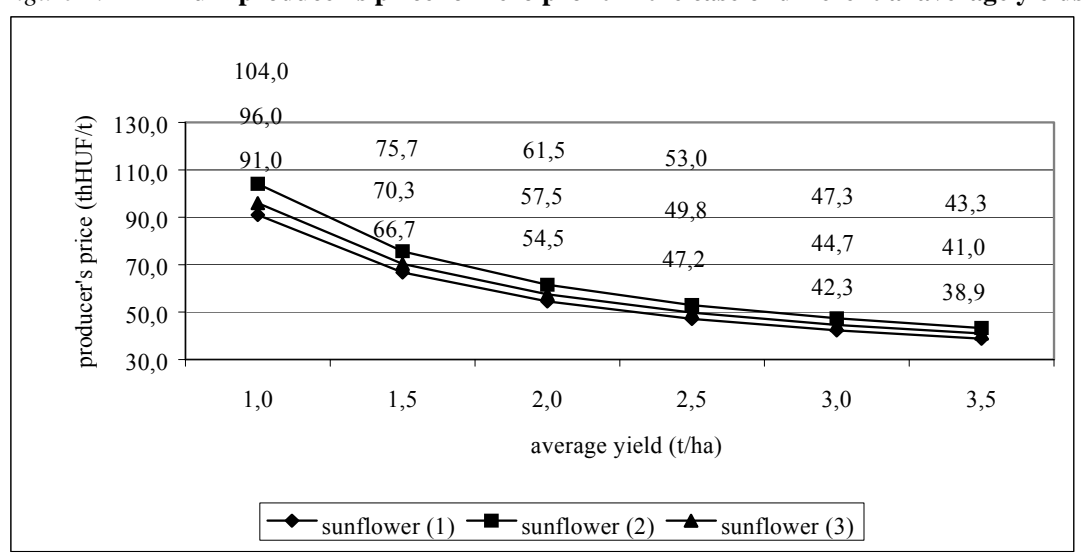

Source: own calculations

Legend: (1), (2), (3): the same as in Figure 1.

The general characteristics of profitability of oilplants not regarding the extremely unfavourable year of 2000 are the following:

$>$ The net profit of oilseed rape is low, that of sunflower is medium, profitability of costs in both plants is favourable and they contribute to the profitable utilisation of movable assets.

$>$ Their gross profit is extremely small, it is not appropriate for employing the family of farmers so they are not recommended for small farms. The small size of farms make it impossible to maintain crop rotation and to use some hired services (e.g. plant protection by air plan).

$>$ Their gross overhead margin is small, thus, it is necessary to produce plants with high production value such as potato, sugar beet, vegetables, fruits to cover the general costs in farming.

$>$ Remaining costs are insignificant, its costs do not burden post-planting after change of branch, which is a great advantage in comparison with the plants produced only by expensive special equipment.

When analysing the branches there may be three sources of deficit:

$>$ Rental fee of land, which should also be considered when using even one's own land as an alternative cost (which is not used in accountancy). This is not a disadvantage in comparison with grains, but they are not compatible on hired land in comparison with plants of high production value.

$>$ Cost of storage (36-60 HUF/t/week), which means $15 \mathrm{HUF} / \mathrm{t} /$ week (plus interest cost) extra cost in comparison with grains. If the production prices remain so low and farmers - expecting higher prices - plan to export their products, additional storage of 1-2 months may be considered in comparison with the pre-contracted, cheaper products.

- Farmers having larger areas will not get landbased subsidy of 4-8 thHUF/ha, although producing oil-plants causes many-sided problems in small farms.
Besides the results in the branches of oil plants, the economic and social aspects should also be considered, which emerge not in the oil plant branch, but because of it. They are the following:

$>$ Sunflower cake and rape cake can substitute sunflower and rape pellets, mainly in cattle branches. Saving of feed costs of 15,500-20,000 $\mathrm{HUF} / \mathrm{t}$ and of VAT of 160-780 HUF/t may be reached according to protein content and market prices.

$>$ They are excellent plants for honey bees, they are capable of gathering raw materials for honey of up to $20-30 \mathrm{~kg}$ from a territory of one hectare. This has a value of 12-18 thHUF/ha.

$>$ If the post-plants after sunflower are cereals the need for potassium fertiliser decreases (90-180 $\mathrm{kg} / \mathrm{ha}$ ) and that of nitrogen fertiliser increases (24-48 kg/ha). Need of nitrogen fertiliser can be reduced after oilseed rape $(40-50 \mathrm{~kg} / \mathrm{ha})$. The savings value is $4,300-8,600 \mathrm{HUF} / \mathrm{ha}$ for sunflower and 4,400-5,400 HUF/ha for oilseed rape.

$>$ The pre-plantation of rape increases the yield of cereals, which has a value of 10-13 thHUF/ha.

$>$ After harvesting oilseed rape - instead of ploughing - using hard till provides proper soil preparation for winter cereals. The differentiation between costs is 5-6 thHUF/ha.

$>$ The costs of harvesting of 4-6 hectares of cereals and of 3-5 hectares of corn can be covered by revenues from one hectare of rape. The latter is true for even sunflower. Interest savings of these depend on plants, the quantity of products and interest conditions, and are the following: 1-3 thHUF/ha, 3-9 thHUF/ha and 1-3.5 thHUF/ha.

$>$ Thanks to the better capacity utilisation of grain harvestes, the cost of amortisation per hectare decreases, which is approximately $10 \%$, or 700 $800 \mathrm{HUF} / \mathrm{ha}$, assuming that the area of grains will be five times larger than that of oil plants.

$>$ A significant advantage of oilseed rape, although it is difficult to quantify, is the fact that it reduces the peak of work, losses from performing work are delayed, and all-day-shifts on the farms. 
Summarized the value of economic advantages of oil plants in related branches may be evaluated as follows (Table 2):

Table 2: Savings in other branches in the case of production of oil plants

\begin{tabular}{|l|r|r|}
\hline Name of branches & Oilseed rape & \multicolumn{1}{c|}{ Unit: thHUF/lower } \\
\hline Cereals & $26-30$ & $8-10$ \\
\hline Cattle* & $32-40$ & $32-40$ \\
\hline Apiculture & $12-18$ & $12-18$ \\
\hline Total & $\mathbf{7 0 - 8 8}$ & $\mathbf{5 2 - 6 8}$ \\
\hline
\end{tabular}

Source: own calculations

Legend: * calculated by 2 t/ha average yield of oil plants

\section{ANALYSING THE COMPETITIVENESS OF BIODIESEL IN COMPARISON WITH GASOLINE}

The closed chain of "oil plant producer /biodiesel factory/ farmer using gasoline" only works if the factory in the centre

$>$ purchases the raw material at a reasonable price (this was illustrated in the previous chapter) and

$>$ gives the gasoline to farmers cheaper or at the same price as it can be purchased at petrol stations demanding back the VAT, the $80 \%$ part from the excise tax according to government regulation of 216/1997 (XII. 1.) Cost of gasoline for farmers on the basis from the MOL-prices of $1^{\text {st }}$ of May 2001 is 112.47 HUF/litre with limitation of land use and branches. Regarding the surplus consumption of 5 to $10 \%$ when using biodiesel, this is equal with biodiesel price of 103-105 HUF/litre for farmers.
The fuel produced in a biodiesel-factory has another advantage for farmers. It is a bureaucratic procedure to require back the different taxes after using gasoline, and its reduction may be favourable for not only for farmers but it would harmonise the would-be requirements of the Common Agricultural Policy of the European Union. Marketing of biodiesel in a closed system would free farmers from office routine in peak time and related paperwork, which has quantitative financial results, too besides relaxed work. Interest-savings of 0.2-0.4 HUF/litre in monthly VAT return, of 0.5-1 HUF/litre in quarterly VAT return and of 1.7-4.4 HUF/litre in yearly VAT return may be reached depending on the fact that the production is based on own capital or credit as well as how much fuel is used and in which production period. The same numbers in excise tax which is required back seven times a year (after workingperiods) 0.2-0.5 HUF/litre and it is 2.8-7.2 HUF/litre when there is common return. It is notable that these savings occur mainly in small farmers, in contrast with the factors of technology. On the other hand as a consequence of lack of information as well as of the inefficiency of the network of agricultural consultants, some small farmers cannot apply for subsidies, even for return of VAT (Szabó, 2000).

In branches producing small quantities of products, even the maximum rate of excise tax cannot be returned. The two analysed branches are typical examples of this. According to my calculations 90.9 litres and 97,3 litres gasoline is needed to produce a hectare of rape and sunflower, respectively. However, the gasoline need of some of the working phases exceeds the supported rate, as is shown in Table 3:

Table 3: Subsidized amount for gasoline used for the production of oil plants

\begin{tabular}{|c|c|c|c|c|}
\hline \multirow[b]{2}{*}{ Stage of work } & \multicolumn{2}{|c|}{ Oilseed rape } & \multicolumn{2}{|c|}{ Sunflower } \\
\hline & $\begin{array}{c}\text { subsidized amount } \\
\text { of gasoline }\end{array}$ & $\begin{array}{c}\text { non-subsidized } \\
\text { amount of gasoline }\end{array}$ & $\begin{array}{c}\text { subsidized amount } \\
\text { of gasoline }\end{array}$ & $\begin{array}{c}\text { non-subsidized } \\
\text { amount of gasoline }\end{array}$ \\
\hline Soil preparation & 37,5 & & 40 & \\
\hline Sowing & 8 & 2,6 & 8 & 2,6 \\
\hline Plant protection & 9 & 9,8 & 9 & 12,3 \\
\hline Fertilizing & 3 & 4,5 & 3 & 4,5 \\
\hline Harvesting & 16,3 & & 16,3 & \\
\hline Transport connected with harvesting & $0,2-0,3$ & & $0,2-0,3$ & \\
\hline Drying & & & & $1-1,6$ \\
\hline Total & 74 & 16,9 & 76,6 & 20,7 \\
\hline
\end{tabular}

Source: Government Regulation of 216/1997 (XII. 1.)

Assuming that the same working phase is not performed in other plants (e.g. as second sowing) on the same area, the cost of gasoline becomes more expensive (124-127 HUF/litre) due to the fact that the excise tax is not returnable. The competitive prices are $115 \mathrm{HUF} /$ litre for oilseed rape and 117 HUF/litre for sunflower under current price conditions. This disadvantage does not occur or occurs rarely in plants requiring deep cultivation or giving high yields.

When calculating economic effects attenuation of fuel should also be considered, which contributes to changing the oil more frequently. This is 5 to $50 \%$ (according to differential measures), which is an extra cost of 0.5 to $4.3 \mathrm{HUF} /$ litre biodiesel.

According to the above mentioned, the biodiesel price of 100-124 HUF/litre may not cause growth in costs, in contrast to gasoline. Using more expensive biodiesel can be reasonable for farmers with small areas and for those who produce extensive field plants with higher yields and whose production is based on credit. 


\section{REFERENCES}

Somogyi, Z.-Dencs, B.-Marton, Gy.-Kovács, K.-Réczey, I.Marosvölgyi, B.-Zsuffa, L. (1999): Az energianövények termesztésének és hasznosításának magyarországi helyzete, különös tekintettel az EU V. K+F keretprogramjához való integrálódás elősegítésére. OMFB tanulmány, Budapest

Szabó, B. (2000): Hortobágy vidékfejlesztése egy családi gazdaság példáján keresztül. Poszter. Óvári Tudományos Napok, Mosonmagyaróvár, II. kötet, 197-201.

Government Regulation of 216/1997 (XII. 1.)

KITE, IKR technologies for sunflower- and oilseed rape producers (1996-1999) 